Historic, archived document

Do not assume content reflects current scientific knowledge, policies, or practices. 



\section{"The Most Beautiful American Conifer"}



UNITED LITHO. \& PTG. COS, ROCHESTER, N. Y.

Photographed by Harlan P. Kelsey at the Arnold Arboretum, Jamaica Plain, Mass.

\section{CAROLINA HEMLOCK}

(Tsuga caroliniana)

"Its dense. dark foliage, sweeping semi-pendulous branches and eventually pyramidal form, combine to give a charm not found in any other evergreen known to cultivation."

HARLAN P. KELSEY, Hardy American Plants, SALEM. MASS, 


\section{CAROLINA HEMLOCK \\ (Tsuga caroliniana) \\ GROWN AT \\ Boxford-Highlands Nursery}

Prices of Specimen Trees, Balled and Burlaped:

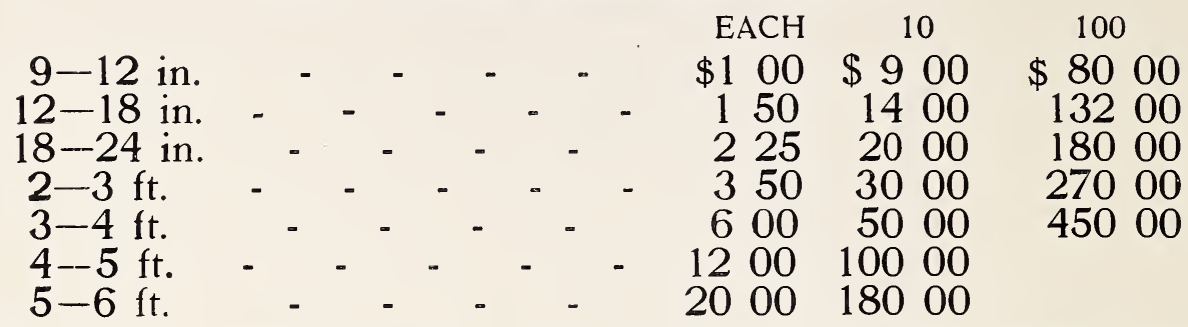

A few larger extra specimens, up to 14 feet, from $\$ 45$ to $\$ 150$ each. $5 \%$ discount for cash with order.

Carolina Hemlock is unique in habit, with dark, dense, tufted foliage on sweeping pendulous branches with a "Japanese effect." It is hardier and more adapted to trying city atmospheres than the Common or Canada Hemlock and seems to thrive in southern latitudes where the latter becomes thin, yellow and unsightly.

After the disastrous spring and winter of 1917-8, Prof. C. S. Sargent, Director of Arnold Arboretum, said of this tree:

"Numerous specimens of the Carolina Hemlock (Tsuga ca:oliniana) have been uninjured by the cold and drouth of the year. This is one of the handsomest of all cone-bearing trees that can be grown in this part of the country."

At Boxford-Highlands Nursery may be seen large solid blocks of Carolina Hemlock, each tree a specimen, regardless of size.

For best results in Spring, orders should be placed early and planting done as soon as the fround can be worked. August and September planting is particularly successful.

\section{CANADA HEMLOCK}

\section{(Tsuga canadensis)}

Prices balled and burlaped:

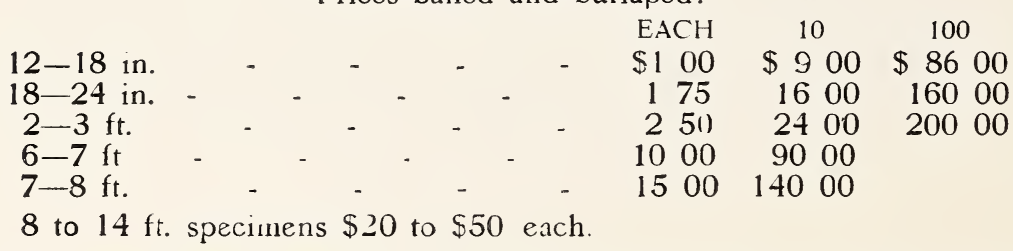

Our beautiful common Hemlock is one of the most conspicuous of our Eastern Mountain Conifers. Does well either in partial shade or in the open and can be kept to any desired size by shearing. A fine hedge plant. Send orders to

HARLAN P. KELSEY, Owner, Salem, Massachusetts.

Catalog of Hardy Amerizan Plants and Specimen Evergreens on request. 